\title{
Social, Environmental and Behavioral Determinants of Asthma Symptoms in Brazilian Middle School Students-A National School Health Survey (Pense 2012)
}

\author{
Rita C. Ribeiro-Silva ${ }^{1, *}$, Deborah C. Malta ${ }^{2}$, Laura C. Rodrigues ${ }^{3}$, Dandara O. Ramos ${ }^{4}(\mathbb{D}$, \\ Rosemeire L. Fiaccone ${ }^{5}$, Daiane B. Machado ${ }^{4}$ and Maurício L. Barreto ${ }^{4,6}$ \\ 1 School of Nutrition, Federal University of Bahia, Salvador 40.110-150, Brazil \\ 2 School of Nursery, Federal University of Minas Gerais, Belo Horizonte 30.130-100, Brazil; \\ dcmalta@uol.com.br \\ 3 Department of Infectious Disease Epidemiology, London School of Hygiene and Tropical Medicine, \\ London WC1E 7HT, UK; laurarodriguesinlondon@gmail.com \\ 4 Center for Data and Knowledge Integration for Health (CIDACS), Institute Gonçalo Moniz (IGM), \\ Oswaldo Cruz Foundation (FIOCRUZ), Salvador 41.745-715, Brazil; dandararamos2@gmail.com (D.O.R.); \\ daianedbm@hotmail.com (D.B.M.); mauricio@ufba.br (M.L.B.) \\ 5 Institute of Mathematics and Statistics, Federal University of Bahia, Salvador 40.170-110, Brazil; \\ rose.fiaccone@gmail.com \\ 6 Institute of Collective Health (ISC), Federal University of Bahia, Salvador 40110-040, Brazil \\ * Correspondence: ritaribeiroufba@gmail.com; Tel.: +55-719-9346-4446
}

Received: 8 October 2018; Accepted: 3 December 2018; Published: 19 December 2018

\begin{abstract}
Biological and psychosocial factors are recognized contributors to the worldwide burden of asthma. However, the relationship between psychosocial factors and asthma symptoms among students in low- and middle-income countries remains underexplored. We aimed to identify socioeconomic, environmental, psychosocial, family-related and lifestyle factors associated with the self-reporting of asthma symptoms in Brazilian adolescents. This is a cross-sectional study using data from the 2012 PeNSE survey $(n=109,104)$. We analyzed the following variables: socioeconomic conditions, demographic characteristics, lifestyle, family context and dynamics, psychosocial indicators, smoking, and exposure to violence. Our outcome variable was the self-report of asthma symptoms in the past 12 months. The prevalence of wheezing was $22.7 \%(21.5-23.9)$. After adjusting for sex, age and the variables from higher hierarchical levels, exposure to violence (feeling unsafe at school, being frequently bullied, being exposed to fights with firearms) and physical aggression by an adult in the family were the environmental factors that showed the strongest associations with self-reporting of asthma symptoms. For psychosocial indicators of mental health and social integration, feelings of loneliness and sleeping problems were the strongest factors, and among individual behavioral factors, the largest associations were found for tobacco consumption. Our findings were consistent with previous studies, showing an association between self-reported asthma symptoms and socio-economic status, family context and dynamics, psychosocial indicators of mental health, exposure to violence and social integration, as well as a sedentary lifestyle and tobacco use.
\end{abstract}

Keywords: wheezing; schoolchildren; psychosocial indicators; violence; lifestyle 


\section{Introduction}

Asthma is a common long-term inflammatory disease of the airways of the lungs. It is characterized by chronic inflammation associated with the hyper-responsivity of the airways, leading to recurrent episodes of wheezing, coughing, chest tightness, and shortness of breath, particularly in the early morning or at night [1].

Asthma is the 14th most important disorder in the world according to years lived with a disability. It is estimated that approximately 334 million people around the world have asthma [2]. The burden of asthma, measured by disability and premature death, is greatest among children (10-14 years old) and the elderly (75-79 years old) [2]. Current studies have estimated that $14 \%$ of children throughout the world experience asthma symptoms [2]. Epidemiologic studies, such as the International Study of Asthma and Allergies in Childhood (ISAAC), registered an average world prevalence of $14.1 \%$ for asthma symptoms in adolescents between the ages of 13 and 14, including 5.1\% in Northern and Eastern Europe, 22\% in Oceania, and 15.9\% in Latin America [3]. Most individuals affected by asthma live in low- and middle-income countries, and its prevalence is increasing at the fastest rate in these countries [2]. In Brazil, the asthma prevalence is one of the highest in Latin America, estimated at $12 \%$ for the adult population [4], and between $13 \%$ [5] and $23 \%$ among children and adolescents [6]. Official data, from government sources, indicates that asthma is still one of the twenty most common reasons for primary care visits in Brazil, representing the third leading cause of hospitalization within the Brazilian public health system (SUS—Sistema Único de Saúde) [7].

Some important risk factors for asthma in children and adolescents have been identified; most of these risk factors are related to a family history of asthma and asthma symptoms, rhinitis or eczema [8], excess humidity at home and infectious respiratory diseases during childhood [9], indicators of poverty or a low socioeconomic status (SES), such as low maternal education and lack of cleanliness at home [10], nutritional status [11,12], psychosocial context [13], sedentary lifestyle [14], factors related to pregnancy and perinatal conditions [15] and genetic factors [16,17]. While a large number of common risk factors have been assessed, these factors are insufficient to explain the development of a multifactorial disease such as asthma. Efforts to define the etiological risk factors for the development and expression of asthma have intensified due to observed increases in the prevalence and severity of asthma throughout the world.

Recent studies have highlighted a complex network of interactions among economic, psychosocial and environmental factors [18]; the inclusion of environmental factors provides us with fresh insight into how various stressors may influence the development of diseases. Epidemiological studies have demonstrated associations $[19,20]$ among stress, social status, quality of social relationships—social networks and an individual's ties to friends, family, work, and community through social and religious groups-and health. These findings led to a paradigm shift that reconsidered the overlap between biological determinants and psychosocial factors in the rising asthma burden. Other studies [21,22] have pointed out associations between stress and psychological factors with asthma symptomatology and bronchoconstriction in the reduced pulmonary flow rates in asthmatic children [23]. These data support an association with stress, although the causal mechanisms linking stress and asthma in children are still unclear.

Biological and psychosocial factors are increasingly recognized contributors to the worldwide burden of asthma. However, the relationship between psychosocial factors and asthma symptoms among students in low- and middle-income countries remains unexamined. We evaluated socioeconomic, environmental, psychosocial, family-related and lifestyle factors associated with the self-report of asthma symptoms in Brazilian adolescents, drawing on the PeNSE survey (Pesquisa Nacional de Saúde do Escolar/National Adolescent School-Based Health Survey), which was conducted in 2012 by the Ministry of Health, Brazil, in collaboration with the Brazilian Institute of Geography and Statistics (IBGE). 


\section{Materials and Methods}

\subsection{Study Design, Population and Data Collection}

This is a cross-sectional study using data from the 2012 edition of the PeNSE survey. The PeNSE sample was chosen to represent the population of 9th grade students in Brazil, including its five regions, 26 state capitals and the Federal District $(n=109,104)$. For the sampling plan, the national territory was stratified as follows: each of the 26 state capitals and the Federal District were defined as a geographic stratum, and the other cities were grouped in each of the five major geographic regions, thus forming another five geographic strata. The sample from each stratum was proportional to the number of schools, according to the administrative dependency of the schools (private and public). For each stratum, a conglomerate sample was selected in two stages, as follows: in the first stage, schools were selected; in the second stage, eligible classrooms were chosen from the selected schools (9th grade, elementary school).

In the strata formed by cities that were not capitals, conglomerates were grouped according to homogeneity and neighboring criteria, thus forming groups of approximately 300 to 600 classrooms. One sample of these groups was selected from each region, and afterwards, schools were selected. Thus, the primary sampling units were the groups of cities and the secondary units were schools; classrooms from these schools were the tertiary sampling units. In both cases, all students in the selected classrooms who were present on the day of data collection formed the sample of students who were invited to participate in the study. For further details on the sampling strategy see PeNSE, 2012 [24].

The 9th grade was chosen because these students, mostly between 13 and 15 years old, have acquired the necessary skills to answer the self-applied structured questionnaire and are likely to be exposed to several risk factors; also, the data from this population enable a comparison with other countries [25]. The questionnaire, comprising approximately 120 questions, was installed on a smartphone.

Two questions about asthma were included [24]: "In the past 12 months, did you have wheezing (or chirping) in your chest?" (yes/no) and "Have you ever had asthma?" (yes/no).

The PeNSE survey was approved by the Ethics Research Committee of the Brazilian Ministry of Health, report NO. 192/2012, concerning registration NO. 16805, of CONEP/MS, on 27/03/2012.

\subsection{Measures}

Socioeconomic conditions: skin color (white (reference), black, brown, other), mother's educational level (no education or unfinished primary education (reference), primary education or unfinished intermediate education, intermediate education or unfinished higher education, higher education), father's educational level (no education or unfinished primary education (reference), primary education or unfinished intermediate education, intermediate education or unfinished higher education, higher education), school's administrative status (private (reference), public), and school's location (capital (reference), outside the capital). A categorized indicator of the person's socioeconomic status (SES) was created according to educational level of the head of the household, possession of various types of household goods (e.g., television sets, desktop or laptop computer), vehicles and number of housekeepers.

Demographic characteristics: age $((<14$ years (reference), 14 years, 15 years, $>15$ years)), (Gender (boys, reference), girls)).

Lifestyle: daily time of sedentary leisure ( $\leq 4 \mathrm{~h}$ sitting watching TV, etc./day (reference), $>4 \mathrm{~h}$ sitting watching TV etc./day), and daily time spent watching TV ( $\leq 2 \mathrm{~h} /$ day(reference), $>2 \mathrm{~h} /$ day).

Family context and dynamics: presence of parents/guardians at home (presence of mother and father (reference), only mother present, only father present, absence of mother and father), parents/guardians acquainted with the leisure activities of their child ((rarely/never, frequently (reference)), parents/guardians attending meals at home (rarely/never, frequently 
(reference)), parents/guardians checking their child's homework ((rarely/never, frequently (reference)), and understanding of the child's problems by the parents/guardians (rare/never, frequent (reference)), parents/guardians rummaging without permission in their child's personal belongings (rarely/never (reference), frequently).

Psychosocial indicators: feeling of loneliness (rare/never (reference), frequent), loss of sleep due to concerns (rare/never (reference), frequent), existence of close friends (less than 3 friends, 3 or more friends (reference)), and child's truancies (rare/never, frequent (reference)).

Smoking: personal tobacco use (yes, no (reference)) and tobacco use in the family (none of the parents/guardians (reference), at least one).

Exposure to violence: being the victim of bullying (rare/never (reference), frequent), feeling of security on the way from home to school (yes (reference), no), feeling of security at school (yes (reference), no), physical aggression committed by an adult family member (yes, no (reference)), and exposure to fights with firearms (yes, no (reference)).

Our outcome variable was the self-report of asthma symptoms in the past 12 months ("In the past 12 months, did you have wheezing or chirping in your chest?" Yes/No).

\subsection{Statistical Analysis}

Analysis was conducted following a predefined conceptual model similar to the framework suggested by Victora et al. [26]. This framework maps the proposed relationships between asthma symptoms and socioeconomic, family-related, individual behavior-related and psychological factors, which are organized in blocks and distributed among three levels (Figure 1). In this way, we implemented a hierarchical effect decomposition (HED) strategy to quantify the association of the factors on the different levels and to disentangle the direct and indirect associations of these factors. According to (HED), the poisson regression (PR) refers to the 'overall effect', i.e., the association adjusted for all potential confounding variables from the same or upper levels of the conceptual framework. For instance, the overall association of block 2 was adjusted for age, gender and SES (located one association level above) and block 3 (located on the same level).

First, tri-variate Poisson regression models were carried out to identify potential asthma determinants by calculating the sex- and age-adjusted prevalence ratios of asthma symptoms in exposed vs non-exposed children. The explanatory variables that, in these initial models, produced a $p$-value $\leq 0.10$ were admitted to the next step, which was an intra-block backward selection, and only covariates with $p$-values $\leq 0.05$ at this second step were included in the multivariate analysis of hierarchical modeling.

Imputation was used for a small subset of the data, regarding the variables composing our SES indicator. The variable informing socioeconomic status (SES) was created according to educational level of the head of the household, possession of various types of household goods (e.g., desktop or laptop computer), vehicles and number of housekeepers. As there was a considerable amount of absence of information regarding maternal educational level (17\%) and also educational level of the father $(23 \%)$, we imputed the mode for these categorical variables, stratifying according to the school's location and administrative status, sex and age of the participant. Sensitivity analysis was performed by comparing the results of tri-variate Poisson regression models without and with imputation of the explanatory variables.

All statistical analyses were carried out using the statistical software package STATA (version 9.2, STATA Corporation, College Station, TX, USA), and weighted data analyses were conducted using the 'svy' family of commands to adjust the prevalence and variance estimates to account for the sample design and clustering. 
Distal context

Block 1 - Socioeconomic conditions
Skin color
Mother's education
Father's education
Economic indicator
School's administrative status

\begin{tabular}{|l|l|}
\hline Demographic characteristics & 1st level \\
Age & \\
Gender & \\
& \\
\hline
\end{tabular}

Intermediate context

\section{Block 2 - Exposure to violence}

Feeling safe on the way from home to school

Feeling safe at school

Being a victim of bullying

Exposure to fights with firearms

\section{Block 3 - Family context and dynamics}

Parents are usually present at home

Parents are aware of the leisure activities of their child

Parents attend meals at home

Parents usually check the child's homework

Parents understand the child's problems

Parents rummage through their child's personal belongings

Physical aggression committed by an adult family member

\begin{tabular}{|l|l|}
\hline Block 4 - Physical environment & 2nd level \\
Tobacco use in the family & \\
& \\
\hline
\end{tabular}

Proximal context

\begin{tabular}{|l|l|l|}
\hline Block 5 - Psychosocial indicators & $\quad \begin{array}{l}\text { Block } 6 \text { - Lifestyle } \\
\text { Weekly duration of physical activity } \\
\text { Feelings of loneliness } \\
\text { Loss of sleep due to concerns } \\
\text { Existence of close friends } \\
\text { Child's truancies }\end{array} \quad \begin{array}{l}\text { Daily time watching TV } \\
\text { Daily time of sedentary leisure } \\
\text { Tobacco personal use }\end{array}$ \\
\hline
\end{tabular}

Asthma symptoms

Wheezing in the last 12 months

Figure 1. Hierarchical Conceptual Model of Risks Associated with Asthma Symptoms in Brazilian Middle School Students (PeNSE Survey, 2012). 


\section{Results}

The prevalence of wheezing in the sample was $22.7 \%$ (21.5-23.9). Table 1 shows the descriptive of the sample and also bivariate associations with self-reports of asthma symptoms. Estimates of PR (prevalence ratio) and the 95\% CI from Poisson multivariate model fitted are shown at Table 2.

In Table 1, the results show that after adjusting for sex and age among the block 1 variables (socioeconomic conditions), only black participants' skin color showed no significant association with a self-report of asthma symptoms. All variables from blocks two, three, four, five and six were associated with a self-report of asthma symptoms in this first step of the analysis sequence.

Table 2 shows the additional two steps of the analysis. In step 2, the intra-block regressions of the asthma symptoms for the variables that had $p$-values $\leq 0.10$ in the tri-variate analysis (step 1 ) were adjusted by sex, age and all of the variables in the block. In step 3, the regression analysis of the asthma symptoms was adjusted by age, sex and the variables that had $p$-values $\leq 0.05$ in step 2 , with further exclusion of the variables that had $p$-values $>0.05$ according to the intra-level analysis.

For block one, the parents' educational level was omitted from the intra-block analysis as being part of the SES indicator. The results from this block alone showed an increased prevalence of asthma symptoms among high SES participants and no significant association with the school administrative status. For blocks two, three, four, five and six, intra-block analysis showed an increased prevalence of reports of asthma symptoms among participants who also reported feeling unsafe at school $(\mathrm{PR}=1.37$; $\mathrm{CI}=1.30-1.45 ; p<0.001)$ or on the way to/from school (PR $=1.19 ; \mathrm{CI}=1.14-1.25 ; p<0.001)$, being frequently bullied ( $\mathrm{PR}=1.36 ; \mathrm{CI}=1.29-1.44 ; p<0.001$ ), being exposed to fights with firearms $(\mathrm{PR}=1.63 ; \mathrm{CI}=1.55-1.70 ; p<0.001)$, lacking parental participation in everyday activities (meals $(\mathrm{PR}=1.11 ; \mathrm{CI}=1.06-1.51 ; p<0.001)$, rarely or never having their homework checked $(\mathrm{PR}=1.13$; $\mathrm{CI}=1.08-1.19 ; p<0.001)$, feeling understood $(\mathrm{PR}=1.19 ; \mathrm{CI}=1.13-1.25 ; p<0.001)$, experiencing parental intrusiveness (rummaging through their personal belongings without permission) $(\mathrm{PR}=1.18$; $\mathrm{CI}=1.13-1.24 ; p<0.001)$, being a victim of physical aggression by an adult family member $(\mathrm{PR}=1.61$; $\mathrm{CI}=1.56-1.67 ; p<0.001)$, tobacco use in the family $(\mathrm{PR}=1.12 ; \mathrm{CI}=1.07-1.18 ; p<0.001)$, feelings of loneliness ( $\mathrm{PR}=1.38 ; \mathrm{CI}=1.33-1.43 ; p<0.001)$, sleep difficulties $(\mathrm{PR}=1.37 ; \mathrm{CI}=1.33-1.41 ; p<0.001)$, having less than three friends $(\mathrm{PR}=1.15 ; \mathrm{CI}=1.10-1.19 ; p<0.001)$, truancies $(\mathrm{PR}=1.45 ; \mathrm{CI}=1.34-1.57$; $p<0.001)$, having more than $4 \mathrm{~h}$ of sedentary leisure ( $\mathrm{PR}=1.17 ; \mathrm{CI}=1.13-1.21 ; p<0.001)$ and being a tobacco user $(\mathrm{PR}=1.53 ; \mathrm{CI}=1.45-1.61 ; p<0.001)$. 
Table 1. Pense 2012-Asthma Symptoms in Brazilian Middle School students: Characteristics Studied and Asthma Symptoms.

\begin{tabular}{|c|c|c|c|c|c|c|c|c|}
\hline \multirow{3}{*}{ Variables } & \multirow{2}{*}{$n$} & \multirow{2}{*}{$\%$} & \multicolumn{6}{|c|}{ Asthma Symptoms } \\
\hline & & & $n$ & $\%^{1}$ & $95 \% \mathrm{CI}$ & $\mathbf{P R}^{2}$ & $95 \% \mathrm{CI}$ & $p$-Value \\
\hline & 109,104 & & 25,038 & 22.7 & $21.5-23.9$ & & & \\
\hline \multicolumn{9}{|l|}{ DEMOGRAPHIC CHARACTERISTICS } \\
\hline \multicolumn{9}{|l|}{ Gender } \\
\hline Boys & 52,015 & 47.7 & 11,062 & 20.7 & $18.9-22.7$ & & & \\
\hline Girls & 57,089 & 52.3 & 13976 & 24.4 & $23.3-25.4$ & 1.17 & $1.08-1.27$ & $<0.001$ \\
\hline \multicolumn{9}{|l|}{ Age } \\
\hline$<14$ years old & 22,443 & 20.6 & 5174 & 23.3 & $21.9-24.9$ & & & \\
\hline 14 years & 50,900 & 46.7 & 11,834 & 23.1 & $21.9-24.4$ & 1.00 & $0.96-1.04$ & 0.10 \\
\hline 15 years & 21,105 & 19.3 & 4769 & 22.2 & $20.9-23.6$ & 0.97 & $0.93-1.01$ & \\
\hline 16 years or older & 14,656 & 13.4 & 3261 & 21.0 & $20.0-22.0$ & 0.92 & $0.85-1.00$ & \\
\hline \multicolumn{9}{|l|}{ SOCIOECONOMIC CONDITIONS } \\
\hline \multicolumn{9}{|l|}{ Self-referred skin color } \\
\hline White & 37,674 & 34.6 & 8699 & 23.0 & $21.4-24.6$ & & & \\
\hline Black & 14,513 & 13.3 & 3259 & 21.8 & $19.4-24.4$ & 0.97 & $0.89-1.05$ & 0.61 \\
\hline Brown & 48,237 & 44.2 & 10,976 & 22.6 & $21.9-23.2$ & 0.98 & $0.93-1.03$ & \\
\hline Others & 8611 & 7.9 & 2104 & 23.4 & $20.8-26.1$ & 1.02 & $0.95-1.08$ & \\
\hline \multicolumn{9}{|l|}{ Mother's education } \\
\hline No education or primary education unfinished & 33,322 & 36.8 & 7522 & 22.4 & $21.7-23.2$ & & & \\
\hline Primary education, or intermediate education unfinished & 15,975 & 17.6 & 3682 & 23.0 & $21.2-24.9$ & 1.02 & $0.98-1.07$ & $<0.001$ \\
\hline Intermediate education, or higher education unfinished & 28,244 & 31.2 & 6769 & 23.7 & $22.3-25.2$ & 1.09 & $1.05-1.13$ & \\
\hline Higher education & 13,036 & 14.4 & 3255 & 25.5 & $24.2-26.9$ & 1.17 & $1.10-1.25$ & \\
\hline \multicolumn{9}{|l|}{ Father's education } \\
\hline No education or primary education unfinished & 35,174 & 41.9 & 7982 & 22.4 & $21.1-23.8$ & & & \\
\hline Primary education, or intermediate education unfinished & 14,114 & 16.8 & 3300 & 23.4 & $21.7-25.2$ & 1.01 & $0.94-1.08$ & $<0.001$ \\
\hline Intermediate education, or higher education unfinished & 22,617 & 26.9 & 5366 & 23.4 & $21.3-25.7$ & 1.06 & $0.96-1.16$ & \\
\hline Higher education & 12,119 & 14.4 & 3049 & 25.9 & $24.7-27.1$ & 1.17 & $1.12-1.23$ & \\
\hline \multicolumn{9}{|l|}{ SES indicator } \\
\hline 1st tertile +2 nd tertile ( $D+C$ class $)$ & 50,430 & 64.4 & 5867 & 24.0 & $23.1-24.9$ & & & \\
\hline 3rd tertile (B class) & 27,868 & 35.6 & 7048 & 25.1 & $23.2-27.1$ & 1.16 & $1.10-1.23$ & $<0.001$ \\
\hline \multicolumn{9}{|l|}{ School's administrative status } \\
\hline Public & 86,599 & 79.4 & 19,495 & 22.3 & $21.1-23.5$ & & & \\
\hline Private & 22,504 & 20.6 & 5543 & 25.0 & $24.1-26.0$ & 1.12 & $1.05-1.19$ & $<0.001$ \\
\hline
\end{tabular}


Table 1. Cont

\begin{tabular}{|c|c|c|c|c|c|c|c|c|}
\hline \multirow{3}{*}{ Variables } & \multirow{2}{*}{$n$} & \multirow{2}{*}{$\%$} & \multicolumn{6}{|c|}{ Asthma Symptoms } \\
\hline & & & $n$ & $\%^{1}$ & $95 \% \mathrm{CI}$ & $\mathbf{P R}^{2}$ & $95 \% \mathrm{CI}$ & $p$-Value \\
\hline & 109,104 & & 25,038 & 22.7 & $21.5-23.9$ & & & \\
\hline \multicolumn{9}{|l|}{ EXPOSURE TO VIOLENCE } \\
\hline \multicolumn{9}{|l|}{ Feeling safe on the way from home to school } \\
\hline Yes & 99,497 & 91.6 & 21,899 & 21.7 & $20.4-23.0$ & & & \\
\hline No & 9150 & 8.4 & 3113 & 33.1 & $31.0-35.4$ & 1.55 & $1.49-1.62$ & $<0.001$ \\
\hline \multicolumn{9}{|l|}{ Feeling safe at school } \\
\hline Yes & 100,126 & 92.4 & 22,004 & 21.5 & $20.4-22.7$ & & & \\
\hline No & 8187 & 7.6 & 2924 & 35.6 & $32.7-38.7$ & 1.69 & $1.60-1.78$ & $<0.001$ \\
\hline \multicolumn{9}{|l|}{ Being victim of bullying } \\
\hline Rarely/never & 101,310 & 93.4 & 22,612 & 21.9 & $20.7-23.2$ & & & \\
\hline Frequently & 7193 & 6.6 & 2350 & 32.8 & $31.3-34.3$ & 1.51 & $1.42-1.61$ & $<0.001$ \\
\hline \multicolumn{9}{|l|}{ Exposure to fights with firearms } \\
\hline No & 96,771 & 89.3 & 20,912 & 21.2 & $20.0-22.5$ & & & \\
\hline Yes & 11,648 & 10.7 & 4053 & 35.6 & $34.3-36.9$ & 1.76 & $1.69-1.85$ & $<0.001$ \\
\hline \multicolumn{9}{|l|}{ FAMILY CONTEXT AND DYNAMICS } \\
\hline \multicolumn{9}{|l|}{ Parents are frequently present at home } \\
\hline Presence of mother and/or father & 101,845 & 93.5 & 23,221 & 22.5 & $21.2-23.8$ & & & \\
\hline Absence of mother and father & 7065 & 6.5 & 1775 & 25.4 & $24.3-26.5$ & 1.13 & $1.04-1.23$ & 0.004 \\
\hline \multicolumn{9}{|l|}{ Parents are aware of the leisure activities of their child } \\
\hline Frequently & 63,916 & 58.9 & 13,815 & 21.3 & $20.3-22.4$ & & & \\
\hline Rarely/never & 44,656 & 41.1 & 11,168 & 24.5 & $23.0-26.1$ & 1.17 & $1.14-1.20$ & $<0.001$ \\
\hline \multicolumn{9}{|l|}{ Parents are present during meals } \\
\hline Frequently & 76,929 & 70.7 & 16,790 & 21.4 & $20.3-22.5$ & & & \\
\hline \multirow{2}{*}{\multicolumn{9}{|c|}{ Parents check the child's homework }} \\
\hline & & & & & & & & \\
\hline Frequently & 33,500 & 31.0 & 6661 & 19.4 & $18.0-20.9$ & & & \\
\hline Rarely/never & 74,756 & 69.0 & 18,256 & 24.3 & $23.2-25.5$ & 1.25 & $1.19-1.30$ & $<0.001$ \\
\hline \multicolumn{9}{|l|}{ Parents are understanding of the child's problems } \\
\hline Frequently & 47,895 & 44.1 & 9495 & 19.4 & 18.0-20.9 & & & \\
\hline Rarely/never & 60,674 & 55.9 & 15,492 & 25.4 & $24.4-26.5$ & 1.31 & $1.26-1.36$ & $<0.001$ \\
\hline \multicolumn{9}{|c|}{ Main carers rummaging without permission through their child's personal belongings } \\
\hline Rarely/never & 91,579 & 84.4 & 20,569 & 22.1 & 20.9-23.3 & & & \\
\hline Frequently & 16,868 & 15.6 & 4393 & 25.9 & 24.3-27.6 & 1.18 & $1.13-1.22$ & $<0.001$ \\
\hline \multicolumn{9}{|c|}{ Physical aggression committed by an adult in the family } \\
\hline No & 97,010 & 89.4 & 20,740 & 21.0 & $19.8-22.3$ & & & \\
\hline Yes & 11,470 & 10.6 & 4233 & 36.8 & 34.9-38.7 & 1.73 & $1.67-1.80$ & $<0.001$ \\
\hline
\end{tabular}


Table 1. Cont

\begin{tabular}{|c|c|c|c|c|c|c|c|c|}
\hline \multirow{3}{*}{ Variables } & \multirow{2}{*}{$n$} & \multirow{2}{*}{$\%$} & \multicolumn{6}{|c|}{ Asthma Symptoms } \\
\hline & & & $n$ & $\%^{1}$ & $95 \% \mathrm{CI}$ & $\mathrm{PR}^{2}$ & $95 \% \mathrm{CI}$ & $p$-Value \\
\hline & 109,104 & & 25,038 & 22.7 & $21.5-23.9$ & & & \\
\hline \multicolumn{9}{|l|}{ PHYSICAL ENVIRONMENT } \\
\hline \multicolumn{9}{|l|}{ Tobacco use in the family } \\
\hline None of the parents/guardians & 76,809 & 72.5 & 16,989 & 21.8 & $20.4-23.3$ & & & \\
\hline At least one & 29,160 & 27.5 & 7317 & 24.6 & $23.7-25.4$ & 1.12 & $1.07-1.18$ & $<0.001$ \\
\hline \multicolumn{9}{|l|}{ PSYCHOSOCIAL INDICATORS } \\
\hline \multicolumn{9}{|l|}{ Feeling of loneliness } \\
\hline Rarely/never & 90,204 & 83.2 & 19,051 & 20.7 & $19.6-21.9$ & & & \\
\hline Frequently & 18,254 & 16.8 & 5972 & 32.4 & $30.6-34.3$ & 1.53 & $1.48-1.59$ & $<0.001$ \\
\hline \multicolumn{9}{|l|}{ Loss of sleep due to concerns } \\
\hline Rarely/never & 97,873 & 90.4 & 21,303 & 21.4 & $20.2-22.6$ & & & \\
\hline Frequently & 10,447 & 9.6 & 3683 & 34.7 & $33.0-36.3$ & 1.59 & $1.55-1.64$ & $<0.001$ \\
\hline \multicolumn{9}{|l|}{ Existence of close friends } \\
\hline 3 or more friends & 87,401 & 80.6 & 19,304 & 21.7 & $20.4-23.0$ & & & \\
\hline Less than 3 friends & 20,983 & 19.4 & 5707 & 26.8 & $25.5-28.2$ & 1.23 & $1.18-1.28$ & $<0.001$ \\
\hline \multicolumn{9}{|l|}{ Child's truancies } \\
\hline Rarely/never & 105,722 & 97.2 & 23,961 & 22.3 & $21.1-23.6$ & & & \\
\hline Frequently & 3092 & 2.8 & 1070 & 34.4 & $32.6-36.2$ & 1.56 & $1.45-1.68$ & $<0.001$ \\
\hline \multicolumn{9}{|l|}{ LIFESTYLE } \\
\hline \multicolumn{9}{|l|}{ Daily time of sedentary leisure } \\
\hline$\leq 4 \mathrm{~h}$ a day & 67,733 & 62.3 & 14,427 & 20.9 & $19.6-22.1$ & & & \\
\hline$>4 \mathrm{~h}$ a day & 40,966 & 37.7 & 10,558 & 25.8 & $24.3-27.4$ & 1.22 & $1.17-1.27$ & $<0.001$ \\
\hline \multicolumn{9}{|l|}{ TV watching } \\
\hline$\leq 2 \mathrm{~h}$ a day & 41,120 & 37.8 & 8832 & 21.0 & $19.5-22.6$ & & & \\
\hline$>2 \mathrm{~h}$ a day & 67,672 & 62.2 & 16,178 & 23.6 & $22.5-24.8$ & 1.11 & $1.06-1.16$ & $<0.001$ \\
\hline \multicolumn{9}{|l|}{ Tobacco use (ever in life, even one or two puffs) } \\
\hline No & 86,113 & 79.1 & 17,979 & 20.6 & $19.3-21.9$ & & & \\
\hline Yes & 22,784 & 20.9 & 7056 & 31.3 & $30.6-32.0$ & 1.56 & $1.47-1.64$ & $<0.001$ \\
\hline
\end{tabular}

${ }^{1}$ weighted proportion and $95 \%$ CI.s. ${ }^{2}$ regressions adjusted by sex and age (STEP 1 of the analysis sequence). 
Table 2. Asthma Symptoms in Brazilian Adolescents Characteristics Studied, Intra-Block and Final Analysis. PeNSE survey 2012.

\begin{tabular}{|c|c|c|c|c|c|c|}
\hline$n:$ Total 108,350, with Asthma Symptoms 25,038, 23.1\% (Weighted \% 22.7, 21.5-23.9) & $\mathbf{P R}^{1}$ & $95 \% \mathrm{CI}$ & $p$-Value & $\mathbf{P R}^{2}$ & $95 \% \mathrm{CI}$ & $p$-Value \\
\hline \multicolumn{7}{|l|}{ DEMOGRAPHIC CHARACTERISTICS } \\
\hline \multicolumn{7}{|l|}{ 5 } \\
\hline \multicolumn{7}{|l|}{ Boys } \\
\hline Girls & 1.17 & $1.08-1.27$ & $<0.001$ & & & \\
\hline \multicolumn{7}{|l|}{ Age } \\
\hline \multicolumn{7}{|l|}{$<14$ years } \\
\hline 14 years & 1.00 & $0.96-1.04$ & 0.10 & & & \\
\hline 15 years & 0.97 & $0.93-1.01$ & & & & \\
\hline$>15$ years & 0.92 & $0.85-1.00$ & & & & \\
\hline \multicolumn{7}{|l|}{ SOCIOECONOMIC CONDITIONS $^{3}$} \\
\hline \multicolumn{7}{|l|}{ SES indicator } \\
\hline \multicolumn{7}{|l|}{ 1st tertile +2 nd tertile $(D+C$ class $)$} \\
\hline 3rd tertile (B class) & 1.15 & $1.09-1.22$ & $<0.001$ & 1.15 & $1.09-1.22$ & $<0.001$ \\
\hline \multicolumn{7}{|l|}{ School's administrative status } \\
\hline \multicolumn{7}{|l|}{ Public } \\
\hline Private & 1.07 & $1.00-1.13$ & 0.037 & 1.07 & $1.00-1.13$ & 0.037 \\
\hline \multicolumn{7}{|l|}{ EXPOSURE TO VIOLENCE } \\
\hline \multicolumn{7}{|l|}{ Feeling safe on the way from home to school } \\
\hline \multicolumn{7}{|l|}{ Yes } \\
\hline No & 1.19 & $1.14-1.25$ & $<0.001$ & 1.15 & $1.05-1.17$ & $<0.001$ \\
\hline \multicolumn{7}{|l|}{ Feeling safe at school } \\
\hline \multicolumn{7}{|l|}{ Yes } \\
\hline No & 1.37 & $1.30-1.45$ & $<0.001$ & 1.29 & $1.18-1.30$ & $<0.001$ \\
\hline \multicolumn{7}{|l|}{ Being victim of bullying } \\
\hline \multicolumn{7}{|l|}{ Rarely/never } \\
\hline Frequently & 1.36 & $1.29-1.44$ & $<0.001$ & 1.29 & $1.10-1.24$ & $<0.001$ \\
\hline \multicolumn{7}{|l|}{ Exposure to fights with firearms } \\
\hline \multicolumn{7}{|l|}{ No } \\
\hline Yes & 1.63 & $1.55-1.70$ & $<0.001$ & 1.48 & $0.71-1.75$ & $<0.001$ \\
\hline
\end{tabular}


Table 2. Cont.

\begin{tabular}{|c|c|c|c|c|c|c|}
\hline$n$ : Total 108,350, with Asthma Symptoms 25,038, 23.1\% (Weighted \% 22.7, 21.5-23.9) & $\mathbf{P R}^{1}$ & $95 \% \mathrm{CI}$ & $p$-Value & $\mathbf{P R}^{2}$ & $95 \% \mathrm{CI}$ & $p$-Value \\
\hline \multicolumn{7}{|l|}{ FAMILY CONTEXT AND DYNAMICS } \\
\hline \multicolumn{7}{|l|}{ Parents are frequently present at home } \\
\hline \multicolumn{7}{|l|}{ Presence of mother and/or father } \\
\hline Absence of mother and father & 1.09 & $1.00-1.18$ & 0.05 & & & \\
\hline \multicolumn{7}{|l|}{ Parents are aware of the leisure activities of their child } \\
\hline \multicolumn{7}{|l|}{ Frequently } \\
\hline Rarely/never & 1.04 & $1.00-1.09$ & 0.05 & & & \\
\hline \multicolumn{7}{|l|}{ Parents are present during meals } \\
\hline \multicolumn{7}{|l|}{ Frequently } \\
\hline Rarely/never & 1.11 & $1.06-1.51$ & $<0.001$ & 1.09 & $1.05-1.14$ & $<0.001$ \\
\hline \multicolumn{7}{|l|}{ Parents check the child's homework } \\
\hline \multicolumn{7}{|l|}{ Frequently } \\
\hline Rarely/never & 1.13 & $1.08-1.19$ & $<0.001$ & 1.13 & $1.08-1.18$ & $<0.001$ \\
\hline \multicolumn{7}{|l|}{ Parents are understanding of the child's problems } \\
\hline \multicolumn{7}{|l|}{ Frequently } \\
\hline Rarely/never & 1.19 & $1.13-1.25$ & $<0.001$ & 1.18 & $1.13-1.23$ & $<0.001$ \\
\hline \multicolumn{7}{|l|}{ Main carers rummaging without permission through their child's personal belongings } \\
\hline Frequently & 1.18 & $1.13-1.24$ & $<0.001$ & 1.14 & $1.09-1.19$ & $<0.001$ \\
\hline \multicolumn{7}{|l|}{ Physical aggression committed by an adult in the family } \\
\hline Yes & 1.61 & $1.56-1.67$ & $<0.001$ & 1.38 & $1.33-1.43$ & $<0.001$ \\
\hline PHYSICAL ENVIRONMENT & & & & & & \\
\hline \multicolumn{7}{|l|}{ No } \\
\hline Yes & 1.12 & $1.07-1.18$ & $<0.001$ & 1.09 & $1.04-1.15$ & 0.001 \\
\hline
\end{tabular}


Table 2. Cont.

\begin{tabular}{|c|c|c|c|c|c|c|}
\hline$n$ : Total 108,350, with Asthma Symptoms 25,038, 23.1\% (Weighted \% 22.7, 21.5-23.9) & $\mathbf{P R}^{1}$ & $95 \%$ CI & $p$-Value & $\mathbf{P R}^{2}$ & $95 \%$ CI & $p$-Value \\
\hline \multicolumn{7}{|l|}{ PSYCHOLOGICAL ASPECTS } \\
\hline \multicolumn{7}{|l|}{ Feeling of loneliness } \\
\hline \multicolumn{7}{|l|}{ Rarely/never } \\
\hline Frequently & 1.38 & $1.33-1.43$ & $<0.001$ & 1.23 & $1.18-1.27$ & $<0.001$ \\
\hline \multicolumn{7}{|l|}{ Loss of sleep due to concerns } \\
\hline \multicolumn{7}{|l|}{ Rarely/never } \\
\hline Frequently & 1.37 & $1.33-1.41$ & $<0.001$ & 1.20 & $1.16-1.24$ & $<0.001$ \\
\hline \multicolumn{7}{|l|}{ Existence of close friends } \\
\hline \multicolumn{7}{|l|}{3 or more friends } \\
\hline Less than 3 friends & 1.15 & $1.10-1.19$ & $<0.001$ & 1.09 & $1.05-1.13$ & $<0.001$ \\
\hline \multicolumn{7}{|l|}{ Child's truancies } \\
\hline \multicolumn{7}{|l|}{ Rarely/never } \\
\hline Frequently & 1.45 & $1.34-1.57$ & $<0.001$ & 1.09 & $1.02-1.18$ & 0.009 \\
\hline LIFESTYLE & & & & & & \\
\hline \multicolumn{7}{|l|}{ Daily time of sedentary leisure } \\
\hline \multicolumn{7}{|l|}{$\leq 4 \mathrm{~h}$ sitting watching TV etc. /day } \\
\hline$>4 \mathrm{~h}$ sitting watching TV etc. / day & 1.17 & $1.13-1.21$ & $<0.001$ & 1.08 & $1.05-1.11$ & $<0.001$ \\
\hline \multicolumn{7}{|l|}{ Daily time of TV watching } \\
\hline \multicolumn{7}{|l|}{$\leq 2 \mathrm{~h} /$ day } \\
\hline$>2 \mathrm{~h} /$ day & 1.04 & $1.00-1.08$ & 0.048 & 1.04 & $1.01-1.08$ & 0.015 \\
\hline \multicolumn{7}{|l|}{ Tobacco personal use } \\
\hline \multicolumn{7}{|l|}{ No } \\
\hline Yes & 1.53 & $1.45-1.61$ & $<0.001$ & 1.27 & $1.22-1.33$ & $<0.001$ \\
\hline
\end{tabular}

1 STEP 2: intra-block regressions on asthma symptoms of the variables whose $p$-values were $\leq 0.10$ in tri-variate analysis (STEP 1); adjusted by sex, age and all the variables in the block.

${ }^{2}$ STEP 3: regression on asthma symptoms adjusted by age, sex and the variables whose $p$-value was $\leq 0.05$ in STEP 2 , with further exclusion of variables whose $p$-value was $>0.05$ at intra-level analysis. ${ }^{3}$ mothers' and fathers' education are not included in this stage of analysis, because they are component of the economic indicator. 
In the final model, after adjusting for sex, age and the variables from the higher hierarchical levels, exposure to violence (feeling unsafe at school, being frequently bullied, being exposed to fights with firearms) and physical aggression by an adult in the family were the environmental factors that showed the strongest associations with a self-report of asthma symptoms; as for psychosocial indicators of mental health and social integration, feelings of loneliness and sleeping problems were the strongest factors, and among individual behavior factors, the largest associations were found for tobacco consumption.

\section{Discussion}

To our knowledge, our study is the first to examine the determinants of asthma symptoms using a large, nationally representative sample of adolescents in Brazil. We quantified the magnitude of the relative mediated risk of these factors using a HED strategy based on a predefined conceptual framework. The results from PeNSE indicate the high prevalence of asthma symptoms $(23.2 \%)$ among 9th grade (elementary school) students, who are usually aged between 13 and 15 years old. This high prevalence was also observed in other regions of the world, such as North America $(21.5 \%)$, Latin America (18.8\%) and Oceania (26.7\%) [27]. The high prevalence of asthma symptoms in the last 12 months among school children highlights asthma as an important health problem among adolescents and demonstrates that Brazil is among the countries with the highest prevalence of asthma in the world. Our findings were consistent with previous studies that showed an association of wheezing with socio-economic status $[10,28]$, family context and dynamics $[19,20]$, psychosocial indicators of mental health and social integration [13,21,22], sedentarism [14], and tobacco consumption [29]. Our study adds information about the association of asthma with violence among children in Brazil.

Among the variables explored in our model, those related to violence and physical aggression showed the strongest associations with asthma symptoms, consistent with previous studies [30-32] and suggesting that violent life events in childhood and adolescence are linked to a greater prevalence of self-reported asthma symptoms. The literature suggests that stress mediates the link between violence and asthma symptoms [32-35]. The oxidative stress hypothesis could explain the relationship among stress, hypothalamic-pituitary-adrenal (HPA) axis alterations, and the immune system [34]. Evidence also suggest that families living in more violent communities keep their children at home for longer periods of time, thus favoring contact with indoor allergens and triggering asthma attacks [36]. In addition, communities with heavier exposure to violence have limited access to health services, thus contributing to the severity of the asthma symptoms [37]. Because of the cross-sectional nature of the data, a plausible alternative explanation for our findings is that children and adolescents with asthma are more likely to be victims of bullying and violence than those who are healthy. However, regardless of the causes of the determined association, our findings highlight the importance of both screening for diseases such as asthma in children and adolescents who have been abused and of being aware of the possibility of abuse in children with asthma.

The association between psychosocial problems and the self-report of asthma symptoms found in our study demonstrated that the prevalence was greater among children who also reported feelings of loneliness and sleep difficulties and had fewer than three friends as well as children with truancies, with the strongest associations for self-reported feelings of loneliness and sleeping problems. These results are in line with the literature on the relationship between child mental health and asthma $[13,35,38]$. Studies have examined the relationship between child mental health problems and chronic diseases; however, the results have been controversial [39]. Although studies have shown heterogeneous effects between behavioral/psychosocial factors and asthma in the literature, a meta-analysis suggested that children with asthma have more behavioral difficulties than healthy children, with the effect of internalizing behaviors being greater than that of externalizing behaviors [40]. The co-occurrence of behavioral problems and asthma has been associated with lower adherence to treatment and an increased frequency and length of hospitalization episodes [41,42]. 
We also found that tobacco was associated with asthma symptoms. The body of evidence confirming the association between tobacco consumption and respiratory disease is substantial and unequivocal [43]. Previous laboratory studies in humans and animals suggest that nicotine is the component that has the most significant detrimental effects on lung growth and collagen deposition. Nicotine affects lung branching through stimulation of alpha-7 nicotinic acetylcholine receptors during the pseudo-glandular phase, resulting in disynaptic lung growth. Changes in the conducting airway structure can decrease airflow and increase resistance, decreasing pulmonary function [43,44]. Smoking status is also an important factor because smoking is associated with poor asthma control and asthma exacerbation; additionally, smokers are more likely to visit the emergency room for asthma and have trouble sleeping due to asthma symptoms [45].

\section{Limitations}

The limitations of this study were primarily due to study design. Indeed, we emphasize that this cross-sectional study cannot establish a causal relationship due to the temporal sequence between exposure and effect. Also, precision of confidence intervals for SES indicator can be affected due to our imputation approach once parameter estimates may be biased. Triggering of asthma following stressful events has been documented $[27,46]$, however, since the data collection was self-reported, the answers for psychosocial events might have been influenced by the students' understanding of the topic. Also, adolescents' reports of asthma symptoms may be imprecise, given their erroneous interpretations of the perceptions of these symptoms, as well as problems understanding the questions. Difficulties were reported by adolescents in understanding the term "wheezing", as used in the ISAAC questionnaire. However, in Brazil, a validation study showed that wheezing in the past 12 months had high sensitivity, specificity and positive and adverse predictive value, reinforcing the concept that this is the key question for the diagnosis of asthma [47].

\section{Conclusions}

Our findings were consistent with previous studies, which have shown an association between the self-report of asthma symptoms and socio-economic status, family context and dynamics, psychosocial indicators of mental health, exposure to violence and social integration, as well as sedentary lifestyle and tobacco use. The results of this study can help managers to develop useful public health interventions in developing countries where there is no public strategy to prevent asthma. An understanding of the multiple factors associated with asthma morbidity, including the increased risk resulting from exposure to violence, will thus lead to the inclusion of psychological measures in the planning of health and childcare services for asthmatic children.

Author Contributions: R.C.R.-S., D.O.R., D.B.M., R.L.F. participated in statistics analysis, interpretation of results and writing of the manuscript. D.C.M., L.C.R., M.L.B. participated in the study design, interpretation of results and revision of the manuscript. All authors read and approved the final manuscript.

Funding: This research received no external funding.

Conflicts of Interest: The authors declare no conflict of interest.

\section{References}

1. Lemanske, R.F., Jr.; Busse, W.W. Asthma: Clinical expression and molecular mechanisms. J. Allergy Clin. Immunol. 2010, 125 (Suppl. 2), S95-S102. [CrossRef]

2. The Global Asthma Report 2014. Available online: http://www.globalasthmareport.org/resources/ resources.php (accessed on 12 September 2017).

3. Lai, C.; Beasley, R.; Crane, J.; Foliaki, S.; Shah, J.; Weiland, S. Global variation in the prevalence and severity of asthma symptoms: Phase three of the International Study of Asthma and Allergies in Childhood (ISAAC). Thorax 2009, 64, 476-483. [CrossRef] 
4. $\quad$ Menezes, A.M.; Wehrmeister, F.C.; Horta, B.; Szwarcwald, C.L.; Vieira, M.L.; Malta, D.C. Prevalence of asthma medical diagnosis among Brazilian adults: National Health Survey, 2013. Revista Brasileira de Epidemiologia 2015, 18 (Suppl. 2), 204-213. [CrossRef] [PubMed]

5. Kuschnir, F.C.; Gurgel, R.Q.; Solé, D.; Costa, E.; Felix, M.M.; de Oliveira, C.L.; de Vasconcellos, M.T.; Kuschnir, M.C. ERICA: Prevalence of asthma in Brazilian adolescents. Revista de Saude Publica 2016, 50 (Suppl. 1), 13s. [CrossRef] [PubMed]

6. Barreto, M.L.; Ribeiro-Silva Rde, C.; Malta, D.C.; Oliveira-Campos, M.; Andreazzi, M.A.; Cruz, A.A. Prevalence of asthma symptoms among adolescents in Brazil: National Adolescent School-based Health Survey (PeNSE 2012). Revista Brasileira de Epidemiologia 2014, 17 (Suppl. 1), 106-115. [CrossRef]

7. Portal da Saúde. Indicadores e Dados Básicos; Ministério de Saúde: Brasília, Brazil, 2008. Available online: http:/ / tabnet.datasus.gov.br (accessed on 12 September 2017).

8. Cooper, P.J.; Chico, M.E.; Vaca, M.G.; Rodriguez, A.; Alcântara-Neves, N.M.; Genser, B.; de Carvalho, L.P.; Stein, R.T.; Cruz, A.A.; Rodrigues, L.C.; et al. Risk factors for asthma and allergy associated with urban migration: Background and methodology of a cross-sectional study in Afro-Ecuadorian school children in Northeastern Ecuador (Esmeraldas-SCAALA Study). BMC Pulm. Med. 2006, 6, 24. [CrossRef]

9. Strina, A.; Barreto, M.L.; Cooper, P.J.; Rodrigues, L.C. Risk factors for non-atopic asthma/wheeze in children and adolescents: A systematic review. Emerg. Themes Epidemiol. 2014, 11, 5. [CrossRef] [PubMed]

10. Kozyrskyj, A.L.; Kendall, G.E.; Jacoby, P.; Sly, P.D.; Zubrick, S.R. Association between socioeconomic status and the development of asthma: Analyses of income trajectories. Am. J. Public Health 2010, 100, 540-546. [CrossRef] [PubMed]

11. Silva Rde, C.; Assis, A.M.; Goncalves, M.S.; Fiaccone, R.L.; Matos, S.M.; Barreto, M.L.; Pinto Ede, J.; Silva, L.A.; Rodrigues, L.C.; Alcantara-Neves, N.M. The prevalence of wheezing and its association with body mass index and abdominal obesity in children. J. Asthma 2013, 50, 267-273. [CrossRef]

12. Ribeiro-Silva Rde, C.; Oliveira-Assis, A.M.; Junqueira, S.B.; Fiaccone, R.L.; Dos Santos, S.M.; Barreto, M.L.; de Jesus Pinto, E.; da Silva, L.A.; Rodrigues, L.C.; Alcantara-Neves, N.M. Food and nutrition insecurity: A marker of vulnerability to asthma symptoms. Public Health Nutr. 2014, 17, 14-19. [CrossRef]

13. Feitosa, C.A.; Santos, D.N.; Barreto do Carmo, M.B.; Santos, L.M.; Teles, C.A.; Rodrigues, L.C.; Barreto, M.L. Behavior problems and prevalence of asthma symptoms among Brazilian children. J. Psychosom. Res. 2011, 71, 160-165. [CrossRef] [PubMed]

14. Moncayo, A.L.; Vaca, M.; Oviedo, G.; Erazo, S.; Quinzo, I.; Fiaccone, R.L.; Chico, M.E.; Barreto, M.L.; Cooper, P.J. Risk factors for atopic and non-atopic asthma in a rural area of Ecuador. Thorax 2010, 65, 409-416. [CrossRef] [PubMed]

15. Rosas-Salazar, C.; Ramratnam, S.K.; Brehm, J.M.; Han, Y.Y.; Boutaoui, N.; Forno, E.; Acosta-Pérez, E.; Alvarez, M.; Colón-Semidey, A.; Canino, G.; et al. Prematurity, atopy, and childhood asthma in Puerto Ricans. J. Allergy Clin. Immunol. 2014, 133, 357-362. [CrossRef]

16. Costa, R.D.; Figueiredo, C.A.; Barreto, M.L.; Alcantara-Neves, N.M.; Rodrigues, L.C.; Cruz, A.A.; Vergara, C.; Rafaels, N.; Foster, C.; Potee, J.; et al. Effect of polymorphisms on TGFB1 on allergic asthma and helminth infection in an African admixed population. Ann. Allergy Asthma Immunol. 2017, 118, 483-488.e1. [CrossRef] [PubMed]

17. Leal, V.N.C.; Genov, I.R.; Mallozi, M.C.; Sole, D.; Pontillo, A. Polymorphisms in inflammasome genes and risk of asthma in Brazilian children. Mol. Immunol. 2018, 93, 64-67. [CrossRef]

18. Beasley, R.; Semprini, A.; Mitchell, E.A. Risk factors for asthma: Is prevention possible? Lancet 2015, 386, 1075-1085. [CrossRef]

19. Yonas, M.A.; Lange, N.E.; Celedon, J.C. Psychosocial stress and asthma morbidity. Curr. Opin. Allergy Clin. Immunol. 2012, 12, 202-210. [CrossRef] [PubMed]

20. Martikainen, P.; Bartley, M.; Lahelma, E. Psychosocial determinants of health in social epidemiology. Int. J. Epidemiol. 2002, 31, 1091-1093. [CrossRef]

21. Wood, B.L.; Miller, B.D.; Lehman, H.K. Review of family relational stress and pediatric asthma: The value of biopsychosocial systemic models. Fam. Process 2015, 54, 376-389. [CrossRef]

22. Rosenberg, S.L.; Miller, G.E.; Brehm, J.M.; Celedon, J.C. Stress and asthma: Novel insights on genetic, epigenetic, and immunologic mechanisms. J. Allergy Clin. Immunol. 2014, 134, 1009-1015. [CrossRef] 
23. Brehm, J.M.; Ramratnam, S.K.; Tse, S.M.; Croteau-Chonka, D.C.; Pino-Yanes, M.; Rosas-Salazar, C.; Litonjua, A.A.; Raby, B.A.; Boutaoui, N.; Han, Y.Y.; et al. Stress and Bronchodilator Response in Children with Asthma. Am. J. Respir. Crit. Care Med. 2015, 192, 47-56. [CrossRef]

24. Brasil. Instituto Brasileiro de Geografia e Estatística. Pesquisa Nacional de Saúde Escolar (PeNSE)—2012. Rio de Janeiro (RJ): IBGE. 2012. Available online: http:/ / portalsaude.saude.gov.br/portalsaude/arquivos / pdf/2013/Jun/20/pense_2012_arquivo_web.pdf (accessed on 13 October 2017).

25. Organização Mundial da Saúde. Social determinants of health and well-being among young people. In Health behaviour in School-Aged Children (HBSC) Study: International Report from the 2009/2010 Survey; WHO: Copenhagen, Denmark, 2012.

26. Victora, C.G.; Huttly, S.R.; Fuchs, S.C.; Olinto, M.T. The role of conceptual frameworks in epidemiological analysis: A hierarchical approach. Int. J. Epidemiol. 1997, 26, 224-227. [CrossRef] [PubMed]

27. Chong Neto, H.J.; Rosario, N.A.; Sole, D.; Latin American, I.G. Asthma and Rhinitis in South America: How Different They Are from Other Parts of the World. Allergy Asthma Immunol. Res. 2012, 4, 62-67. [CrossRef] [PubMed]

28. Cooper, P.J.; Rodrigues, L.C.; Barreto, M.L. Influence of poverty and infection on asthma in Latin America. Curr. Opin. Allergy Clin. Immunol. 2012, 12, 171-178. [CrossRef]

29. Mejias, S.G.; Ramphul, K. Prevalence and Associated Risk Factors of Bronchial Asthma in Children in Santo Domingo, Dominican Republic. Cureus 2018, 10, E2211. [CrossRef] [PubMed]

30. Ramratnam, S.K.; Han, Y.Y.; Rosas-Salazar, C.; Forno, E.; Brehm, J.M.; Rosser, F.; Marsland, A.L.; Colón-Semidey, A.; Alvarez, M.; Miller, G.E.; et al. Exposure to gun violence and asthma among children in Puerto Rico. Respir. Med. 2015, 109, 975-981. [CrossRef]

31. Sternthal, M.J.; Jun, H.J.; Earls, F.; Wright, R.J. Community violence and urban childhood asthma: A multilevel analysis. Eur. Respir. J. 2010, 36, 1400-1409. [CrossRef]

32. Alves Gda, C.; Santos, D.N.; Feitosa, C.A.; Barreto, M.L. Community violence and childhood asthma prevalence in peripheral neighborhoods in Salvador, Bahia State, Brazil. Cadernos de Saude Publica 2012, 28, 86-94. [CrossRef]

33. Walker, J.; Lewis-Land, C.; Kub, J.; Tsoukleris, M.; Butz, A. The effect of violence on asthma: Are our children facing a double-edged sword? J. Community Health 2008, 33, 384-388. [CrossRef] [PubMed]

34. Priftis, K.N.; Chrousos, G.P. Neuroimmunomodulation in asthma: Focus on the hypothalamic-pituitaryadrenal axis. Neuroimmunomodulation 2009, 16, 263-264. [CrossRef] [PubMed]

35. Jesenak, M.; Zelieskova, M.; Babusikova, E. Oxidative Stress and Bronchial Asthma in Children-Causes or Consequences? Front. Pediatr. 2017, 5, 162. [CrossRef] [PubMed]

36. Wright, R.J.; Mitchell, H.; Visness, C.M.; Cohen, S.; Stout, J.; Evans, R.; Gold, D.R. Community violence and asthma morbidity: The Inner-City Asthma Study. Am. J. Public Health 2004, 94, 625-632. [CrossRef] [PubMed]

37. Apter, A.J.; Garcia, L.A.; Boyd, R.C.; Wang, X.; Bogen, D.K.; Ten Have, T. Exposure to community violence is associated with asthma hospitalizations and emergency department visits. J. Allergy Clin. Immunol. 2010, 126, 552-557. [CrossRef] [PubMed]

38. Arif, A.A.; Korgaonkar, P. The association of childhood asthma with mental health and developmental comorbidities in low-income families. J. Asthma 2016, 53, 277-281. [CrossRef]

39. Alati, R.; O'Callaghan, M.; Najman, J.M.; Williams, G.M.; Bor, W.; Lawlor, D.A. Asthma and internalizing behavior problems in adolescence: A longitudinal study. Psychosom. Med. 2005, 67, 462-470. [CrossRef] [PubMed]

40. McQuaid, E.L.; Kopel, S.J.; Nassau, J.H. Behavioral adjustment in children with asthma: A meta-analysis. J. Dev. Behav. Pediatr. 2001, 22, 430-439. [CrossRef] [PubMed]

41. Wright, R.J.; Rodriguez, M.; Cohen, S. Review of psychosocial stress and asthma: An integrated biopsychosocial approach. Thorax 1998, 53, 1066-1074. [CrossRef]

42. Weil, C.M.; Wade, S.L.; Bauman, L.J.; Lynn, H.; Mitchell, H.; Lavigne, J. The relationship between psychosocial factors and asthma morbidity in inner-city children with asthma. Pediatrics 1999, 104, 1274-1280. [CrossRef]

43. Vanker, A.; Gie, R.P.; Zar, H.J. The association between environmental tobacco smoke exposure and childhood respiratory disease: A review. Expert Rev. Respir. Med. 2017, 11, 661-673. [CrossRef]

44. Gibbs, K.; Collaco, J.M.; McGrath-Morrow, S.A. Impact of Tobacco Smoke and Nicotine Exposure on Lung Development. Chest 2016, 149, 552-561. [CrossRef] 
45. Perret, J.L.; Bonevski, B.; McDonald, C.F.; Abramson, M.J. Smoking cessation strategies for patients with asthma: Improving patient outcomes. J. Asthma Allergy 2016, 9, 117-128. [CrossRef] [PubMed]

46. Sandberg, S.; Paton, J.Y.; Ahola, S.; McCann, D.C.; McGuinness, D.; Hillary, C.R.; Oja, H. The role of acute and chronic stress in asthma attacks in children. Lancet 2000, 356, 982-987. [CrossRef]

47. Wandalsen, N.F.; Gonzalez, C.; Wandalsen, G.F.; Solé, D. Avaliação de critérios para o diagnóstico de asma através de um questionário epidemiológico. Jornal Brasileiro de Pneumologia 2009, 35, 199-205. [CrossRef] [PubMed]

(c) 2018 by the authors. Licensee MDPI, Basel, Switzerland. This article is an open access article distributed under the terms and conditions of the Creative Commons Attribution (CC BY) license (http://creativecommons.org/licenses/by/4.0/). 